\title{
REVIEW
}

\section{Health benefits of physical activity: the evidence}

\author{
Darren E.R. Warburton, Crystal Whitney Nicol, Shannon S.D. Bredin
}

\section{ABSTRACT}

The primary purpose of this narrative review was to evaluate the current literature and to provide further insight into the role physical inactivity plays in the development of chronic disease and premature death. We confirm that there is irrefutable evidence of the effectiveness of regular physical activity in the primary and secondary prevention of several chronic diseases (e.g., cardiovascular disease, diabetes, cancer, hypertension, obesity, depression and osteoporosis) and premature death. We also reveal that the current Health Canada physical activity guidelines are sufficient to elicit health benefits, especially in previously sedentary people. There appears to be a linear relation between physical activity and health status, such that a further increase in physical activity and fitness will lead to additional improvements in health status.

CMAJ 2006;174(6):80I-9

$\mathrm{P}$ hysical inactivity is a modifiable risk factor for cardiovascular disease and a widening variety of other chronic diseases, including diabetes mellitus, cancer (colon and breast), obesity, hypertension, bone and joint diseases (osteoporosis and osteoarthritis), and depression. ${ }^{1-14}$ The prevalence of physical inactivity (among $5 \mathrm{r} \%$ of adult Canadians) is higher than that of all other modifiable risk factors. ${ }^{15}$ In this article we review the current evidence relating to physical activity in the primary and secondary prevention of premature death from any cause, cardiovascular disease, diabetes, some cancers and osteoporosis. We also discuss the evidence relating to physical fitness and musculoskeletal fitness and briefly describe the independent effects of frequency and intensity of physical activity. (A glossary of terms related to the topic appears in Appendix I). In a companion paper, to be published in the Mar. 28 issue, we will review how to evaluate the healthrelated physical fitness and activity levels of patients and will provide exercise recommendations for health.

Several authors have attempted to summarize the evidence in systematic reviews and meta-analyses. These evaluations are often overlapping (reviewing the same evidence). Some of the most commonly cited cohorts have been described in different studies over time as more data accumulate (see Appendix 2, available online at www.cmaj.ca/cgi/content/full//174/6 /80I/DCI). In this review, we searched the literature using the key words "physical activity," "health," "health status," "fitness," "exercise," "chronic disease," "mortality" and disease- specific terms (e.g., "cardiovascular disease," "cancer," "diabetes" and "osteoporosis"). Using our best judgment, we selected individual studies that were frequently included in systematic reviews, consensus statements and meta-analyses and considered them as examples of the best evidence available. We also have included important new findings regarding the relation between physical activity and fitness and allcause and cardiovascular-related mortality.

\section{All-cause and cardiovascular-related death}

\section{Primary prevention}

Since the seminal work of Morris and colleagues in the I95 $\mathrm{OS}^{16,17}$ and the early work of Paffenbarger and colleagues in the $1970 \mathrm{~s},{ }^{18,19}$ there have been numerous long-term prospective follow-up studies (mainly involving men but more recently women also) that have assessed the relative risk of death from any cause and from specific diseases (e.g., carciovascular disease) associated with physical inactivity. ${ }^{6,20-26}$

Both men and women who reported increased levels of physical activity and fitness were found to have reductions in relative risk (by about $20 \%-35 \%{ }^{27,28}$ ) of death (see Appendix 2, available at www.cmaj.ca/cgi/content/full/174/6/80r/DCI). For example, in a study involving healthy middle-aged men and women followed up for 8 years, the lowest quintiles of physical fitness, as measured on an exercise treadmill, were associated with an increased risk of death from any cause compared with the top quintile for fitness (relative risk among men $3.4,95 \%$ confidence interval [CI] 2.0 to 5.8 , and among women $4.7,95 \% \mathrm{CI} 2.2$ to 9.8). ${ }^{7}$

Recent investigations have revealed even greater reductions in the risk of death from any cause and from cardiovascular disease. For instance, being fit or active was associated with a greater than $50 \%$ reduction in risk. ${ }^{29}$ Furthermore, an increase in energy expenditure from physical activity of $1000 \mathrm{kcal}$ (4200 $\mathrm{kJ}$ ) per week or an increase in physical fitness of 1 MET (metabolic equivalent) was associated with a mortality benefit of about $20 \%$. Physically inactive middle-aged women (engaging in less than I hour of exercise per week) experienced a $52 \%$ increase in all-cause mortality, a doubling of cardiovascularrelated mortality and a $29 \%$ increase in cancer-related mortality compared with physically active women..$^{30}$ These relative risks are similar to those for hypertension, hypercholesterolemia and obesity, and they approach those associated with moderate cigarette smoking. Moreover, it appears that people who are fit 
yet have other risk factors for cardiovascular disease (see Fig. I) may be at lower risk of premature death than people who are sedentary with no risk factors for cardiovascular disease. ${ }^{31-33}$

An increase in physical fitness will reduce the risk of premature death, and a decrease in physical fitness will increase the risk. ${ }^{34-37}$ The effect appears to be graded, ${ }^{34,35}$ such that even small improvements in physical fitness are associated with a significant reduction in risk (Fig. 2). In one study, ${ }^{35}$ participants with the highest levels of physical fitness at baseline and who maintained or improved their physical fitness over a prolonged period had the lowest risk of premature death (Fig. 2). Modest enhancements in physical fitness in previously sedentary people have been associated with large improvements in health status. ${ }^{38}$ For instance, in another study, people who went from unfit to fit over a 5 -year period had a reduction of $44 \%$ in the relative risk of death compared with people who remained unfit. ${ }^{36}$

A recent systematic review of the literature regarding primary prevention in women ${ }^{39}$ revealed that there was a graded inverse relation between physical activity and the risk of cardiovascular-related death, with the most active women having a relative risk of 0.67 (95\% CI 0.52 to 0.85 ) compared with the least active group. These protective effects were seen with as little as 1 hour of walking per week.

In summary, observational studies provide compelling evidence that regular physical activity and a high fitness level are associated with a reduced risk of premature death from any cause and from cardiovascular disease in particular among

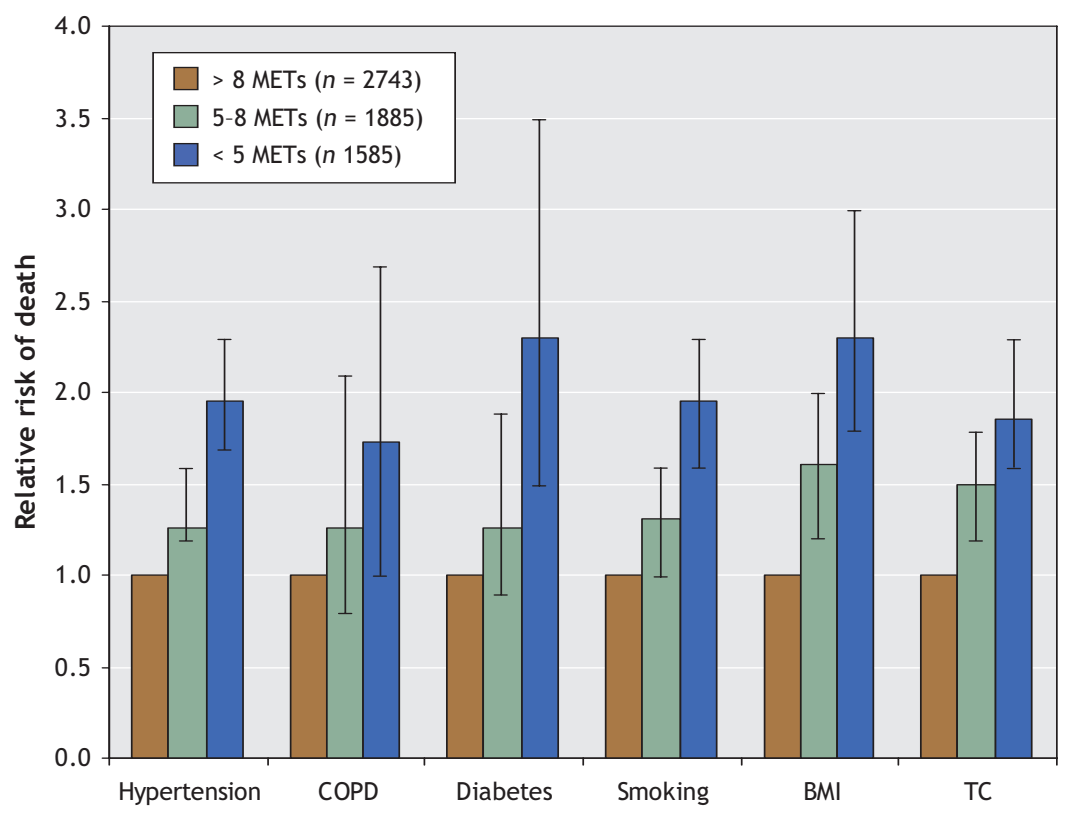

Fig. 1: Relative risks of death from any cause among participants with various risk factors (e.g., history of hypertension, chronic obstructive pulmonary disease [COPD], diabetes, smoking, elevated body mass index $[\mathrm{BMI} \geq 30]$ and high total cholesterol level $[\mathrm{TC} \geq 5.70 \mathrm{mmol} / \mathrm{L}$ ) who achieved an exercise capacity of less than 5 METs (metabolic equivalents) or 5-8 METs, as compared with participants whose exercise capacity was more than 8 METs. Error bars represent $95 \%$ confidence intervals. Adapted, with permission, from Myers et al ${ }^{38}$ (N EnglJ Med 2002;346:793801). Copyright $\odot 2002$ Massachusetts Medical Society. All rights reserved. asymptomatic men and women. Furthermore, a doseresponse relation appears to exist, such that people who have the highest levels of physical activity and fitness are at lowest risk of premature death (as discussed later).

\section{Secondary prevention of cardiovascular disease}

The benefits of physical activity and fitness extend to patients with established cardiovascular disease. ${ }^{40,41}$ This is important because, for a long time, rest and physical inactivity had been recommended for patients with heart disease. Unlike studies of primary prevention, many studies of secondary prevention are RCTs (see Appendix 2, available at www.cmaj.ca/cgi /content/full/I74/6/80r/DCI). Several systematic reviews have clearly shown the importance of engaging in regular exercise to attenuate or reverse the disease process in patients with cardiovascular disease. For instance, a systematic review and meta-analysis of 48 clinical trials ${ }^{5}$ revealed that, compared with usual care, cardiac rehabilitation significantly reduced the incidence of premature death from any cause and from cardiovascular disease in particular. An energy expenditure of about I $600 \mathrm{kcal}(6720 \mathrm{~kJ})$ per week has been found to be effective in halting the progression of coronary artery disease, and an energy expenditure of about $2200 \mathrm{kcal}$ (9240 kJ) per week has been shown to be associated with plaque reduction in patients with heart disease. ${ }^{42,43}$ Low-intensity exercise training (e.g., exercise at less than $45 \%$ of maximum aerobic power) has also been associated with an improvement in health status among patients with cardiovascular disease. ${ }^{44}$ However, the minimum training intensity recommended for patients with heart disease is generally $45 \%$ of heart rate reserve. ${ }^{43}$

In summary, regular physical activity is clearly effective in the secondary prevention of cardiovascular disease and is effective in attenuating the risk of premature death among men and women.

\section{Diabetes mellitus}

\section{Primary prevention}

Both aerobic and resistance types of exercise have been shown to be associated with a decreased risk of type 2 diabetes. ${ }^{9,10,45-48}$ In a large prospective study, ${ }^{46}$ each increase of $500 \mathrm{kcal}(2 \mathrm{IO0} \mathrm{kJ})$ in energy expenditure per week was associated with a decreased incidence of type 2 diabetes of $6 \%$ (relative risk $0.94,95 \% \mathrm{CI}-0.90$ to 0.98$)$ ). This benefit was particularly evident among people at high risk of diabetes (i.e., those with a high body mass index), a finding that has been supported by several other investigators. ${ }^{47,49}$ For instance, among 2I 27I male physicians, those who reported weekly physical activity sufficient to cause a sweat had a reduced incidence of type 2 diabetes. ${ }^{47}$ Moderately intense levels of physical activity ( $\geq 5.5$ METs for at least 40 minutes per week) and of cardiovascular fitness (> 3I mL oxygen per kilogram per min- 
ute) have also been shown to be protective against the development of type 2 diabetes in middle-aged men, ${ }^{48}$ with an even greater effect among those at high risk of diabetes.

Several investigators have reported a reduced incidence of type 2 diabetes among high-risk people (e.g., those who are overweight) after lifestyle interventions..$^{50,51} \mathrm{~A}$ review of RCTs on the topic ${ }^{52}$ concluded that modest weight loss through diet and exercise reduced the incidence of the disease among high-risk people by about $40 \%-60 \%$ over $3-4$ years. In one of the RCTs, ${ }^{53}$ a lifestyle intervention that included moderate physical activity for at least 150 minutes per week was found to be more effective than metformin alone in reducing the incidence of diabetes. It showed that only 7 people would need to be "treated" with the lifestyle intervention to prevent a single case of diabetes over a 3year period, compared with I4 people given metformin. ${ }^{53}$

In summary, increasing research supports the importance of regular physical activity for the primary prevention of type 2 diabetes. Further research is warranted to uncover the ideal methods (e.g., resistance v. aerobic training) and intensity levels of exercise.

\section{Secondary prevention}

Exercise interventions are also effective in the management of diabetes. One prospective cohort study showed that walking at least 2 hours per week was associated with a reduction in the incidence of premature death of $39 \%-54 \%$ from any cause and of $34 \%-53 \%$ from cardiovascular disease among patients with diabetes. ${ }^{49}$ Moreover, walking that led to moderate increases in heart and breathing rates was associated with significant reductions in all-cause mortality (hazard rate ratio $0.57,95 \% \mathrm{CI}$ $0.4 \mathrm{I}$ to 0.80 ) and cardiovascular-related mortality (hazard rate ratio $0.69,95 \%$ CI 0.43 to I.09)..$^{49}$ In another cohort study, ${ }^{54}$ physically inactive men with established type 2 diabetes had a I.7-fold increased risk of premature death compared with physically active men with type 2 diabetes. This difference has also been observed among people with metabolic syndrome..$^{55}$

Several clinical trials have been conducted on the topic..$^{56-63}$ Both aerobic and resistance training have been shown to be of benefit for the control of diabetes; however, resistance training may have greater benefits for glycemic control than aerobic training may have. ${ }^{58} \mathrm{~A}$ meta-analysis of $\mathrm{I} 4$ controlled trials (II randomized) revealed that exercise interventions resulted in a small but clinically and statistically significant reduction in glycosylated hemoglobin (o.66\%) compared with no exercise intervention; $;^{64}$ in most of the trials, participants in both the exercise and control groups were treated concurrently with oral hypoglycemic agents. This level of change is similar to that observed in studies comparing intensive glucose-lowering therapy with conventional treatments, a change that is known to be associated with a $42 \%$ reduction in diabetes-related mortality. ${ }^{64}$

In summary, exercise interventions for patients with diabetes are beneficial in improving glucose homeostasis. Prospective studies with adequate follow-up show a strong association between exercise and reduced rates of death from any cause and from diabetes in particular. Future research will need to concentrate on examining the effects of dose (intensity and frequency of exercise).

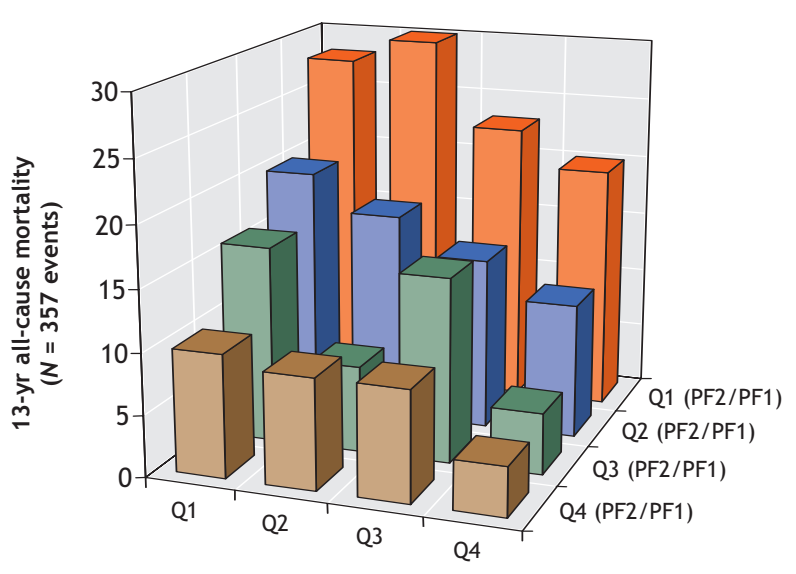

Baseline fitness quartile

Fig. 2: Relation between changes in physical fitness and changes in mortality over time. Participants were evaluated at baseline $\left(P_{1}\right)$ and again 13 years later $\left(P_{2}\right)$. The ratio of $\mathrm{PF}_{2} / \mathrm{PF}_{1} \times 100$ was calculated to evaluate changes in physical fitness over the study period compared with fitness level at baseline. For this figure, participants were grouped according to fitness quartiles (Q1 = least fit, $\mathrm{Q}_{4}=$ most fit) for the baseline evaluation and to quartiles for change in fitness from baseline to 13-year follow-up (Q1 PF2/PF1 = least change, $\mathrm{Q}_{4} \mathrm{PF}_{2} / \mathrm{PF}_{1}=$ most change). Adapted, with permission, from Erikssen et $\mathrm{al}^{35}$ (Lancet 1998;352:759-62).

\section{Cancer}

\section{Primary prevention}

Several seminal reviews have been published regarding the relation between cancer and routine physical activity ${ }^{65-67}$ (see Appendix 2, available at www.cmaj.ca/cgi/content/full/174/6 /80I/DCI). Of the available literature (including over roo epidemiologic studies ${ }^{65}$ ), it appears that routine physical activity, whether as part of a job or as a leisure activity, is associated with reductions in the incidence of specific cancers, in particular colon and breast cancer. ${ }^{67-71} \mathrm{~A}$ systematic review of epidemiologic studies revealed that moderate physical activity (> 4.5 METs [equivalent to mowing the lawn]) was associated with a greater protective effect than activities of less intensity. ${ }^{65}$ Physically active men and women exhibited a 30\%-40\% reduction in the relative risk of colon cancer, and physically active women a $20 \%-30 \%$ reduction in the relative risk of breast cancer compared with their inactive counterparts. ${ }^{65}$

In summary, there is compelling evidence that routine physical activity is associated with reductions in the incidence of specific cancers, in particular breast and colon cancer.

\section{Secondary prevention}

There is a paucity of information regarding the effectiveness of physical activity in preventing death from cancer or from any cause in patients with cancer. An early (5.5-year) follow-up study involving women with breast cancer revealed little associ- 
ation between total recreational physical activity and the risk of death from breast cancer $;{ }^{72}$ however, the study had some important limitations. ${ }^{73}$ Two recent follow-up studies involving cancer patients (breast and colon cancer) revealed that increased self-reported physical activity was associated with a decreased recurrence of cancer and risk of death from cancer. ${ }^{74,75}$ One investigation ${ }^{74}$ revealed a reduction of $26 \%-40 \%$ in the relative risk of cancer-related death and recurrence of breast cancer among the most active women compared with the least active. Other studies have shown similar associations. ${ }^{75,76}$ There are ongoing efforts to try to understand the mechanism of this survival effect, including the effects of exercise on the effectiveness of chemotherapy. ${ }^{77}$ Regular physical activity has also been shown to be associated with an improvement in overall quality of life and health status of patients with cancer..$^{78-82}$

In summary, regular physical activity appears to confer a health benefit to patients with established cancer. However, further research is warranted to examine its role in the secondary prevention of cancer. In particular, large RCTs evaluating the effectiveness of an exercise intervention are required to fully elucidate the importance of regular physical activity for the health status of patients with cancer.

\section{Osteoporosis}

\section{Primary prevention}

Weight-bearing exercise, especially resistance exercise, appears to have the greatest effects on bone mineral density. In one review, ${ }^{10}$ several cross-sectional reports revealed that people who did resistance training had increased bone mineral density compared with those who did not do such training. Furthermore, athletes who engaged in high-impact sports tended to have increased bone mineral density compared with athletes who engaged in low-impact sports. ${ }^{10}$

Numerous longitudinal studies have examined the effects of exercise training on bone health in children, adolescents, and young, middle-aged and older adults (see relevant reviews $^{83-86}$ and Appendix 2, available at www.cmaj.ca/cgi /content/full/174/6/80r/DCI). Although the numbers of studies and total participants examined are relatively small compared with those in the cardiovascular literature, there is compelling evidence that routine physical activity, especially weight-bearing and impact exercise, prevents bone loss associated with aging. In a meta-analysis of RCTs, exercise training programs were found to prevent or reverse almost $\mathrm{I} \%$ of bone loss per year in the lumbar spine and femoral neck in both pre- and postmenopausal women. ${ }^{87}$ Exercise training appears to significantly reduce the risk and number of falls..$^{88-92}$

The risk and incidence of fractures is also reduced among active people. ${ }^{93-95}$ Among 3262 healthy men (mean age 44 years) followed for 21 years, ${ }^{96}$ intense physical activity at baseline was associated with a reduced incidence of hip fracture (hazard ratio $0.38,95 \% \mathrm{CI}$ 0.I6 to 0.9I). This observation supports findings from an earlier investigation in which fracture rates were lower among people who performed more weight-bearing activities than among sedentary people. ${ }^{97}$
In summary, routine physical activity appears to be important in preventing loss of bone mineral density and osteoporosis, particularly in postmenopausal women. The benefits clearly outweigh the potential risks, particularly in older people.

\section{Secondary prevention}

Preliminary evidence from an RCT indicates that exercise training is effective in improving bone density in older women (75-85 years of age) with low bone mineral density. ${ }^{98}$ In this 6month RCT, 98 women were randomly assigned to participate in resistance training $(n=32)$, agility training $(n=34)$ or stretching (sham exercise, $n=32$ ). Agility training resulted in a significant increase in cortical bone density by $0.5 \%$ (standard error of the mean [SEM] $0.2 \%$ ) at the tibial shaft, and resistance training resulted in a significant increase in cortical bone density by $\mathrm{I} .4 \%$ (SEM $0.6 \%$ ) at the radial shaft; the stretching group experienced losses in cortical bone density. ${ }^{98}$ Furthermore, a study involving early postmenopausal osteopenic women revealed that a 2 -year intensive training program was effective in attenuating the rate of bone loss. ${ }^{99}$

In summary, preliminary evidence indicates that regular physical activity is an effective secondary preventive strategy for the maintenance of bone health and the fight against osteoporosis.

\section{Physical activity or physical fitness?}

Physical fitness refers to a physiologic state of well-being that allows one to meet the demands of daily living or that provides the basis for sport performance, or both. Health-related physical fitness involves the components of physical fitness related to health status, including cardiovascular fitness, musculoskeletal fitness, body composition and metabolism. In large epidemiologic investigations, physical activity and physical fitness are often used interchangeably, with fitness commonly being treated as a more accurate (albeit indirect) measure of physical activity than self-report. ${ }^{100}$

Physical fitness appears to be similar to physical activity in its relation to morbidity and mortality ${ }^{2,34}$ but is more strongly predictive of health outcomes than physical activity. ${ }^{6,29,100}$ Most analyses have shown a reduction of at least $50 \%$ in mortality among highly fit people compared with low-fit people (see Appendix 2, available at www.cmaj.ca/cgi/content/full /I74/6/80I/DCI). ${ }^{29}$

Nonetheless, both physical activity and fitness are strong predictors of risk of death. ${ }^{29}$ To obtain accurate estimates of physical activity, many fitness consultants rely on primary (criterion and "gold") standards for the measurement of energy expenditure, such as direct observation of movement or, in the laboratory, the doubly labelled water technique or indirect calorimetry. ${ }^{101}$ On a practical basis, however, measures of physical activity and energy expenditure are obtained by using heart rate monitors and motion sensors (pedometers and accelerometers). These devices will be briefly reviewed in the companion article in the Mar. 28 issue.

The assessment of physical fitness is often not feasible or practical in large population-based investigations. Fortu- 
nately such studies have consistently shown an inverse gradient of health risk across self-reported physical activity groups. From a public health perspective, Blair and colleagues ${ }^{6}$ have argued that it is preferable to encourage people to become more physically active rather than to become physically fit, since, as they stated, sedentary people will likely achieve the latter if they do the former.

\section{Musculoskeletal fitness: a paradigm shift}

Improvements in indicators of health status can occur as a result of increasing physical activity levels in the absence of changes in aerobic fitness. This is particularly evident in elderly populations, where regular physical activity can lead to reductions in risk factors for chronic disease and disability ${ }^{3,9,10}$ without markedly changing traditional physiologic performance markers (e.g., cardiac output and oxidative potential). ${ }^{3}$ Furthermore, routine physical activity can improve musculoskeletal fitness. ${ }^{9,10}$ There is increasing evidence that enhanced musculoskeletal fitness is associated with an improvement in overall health status and a reduction in the risk of chronic disease and disability. ${ }^{9,10}$ This research has led to a shift in focus in research related to the health benefits of activities that tax the musculoskeletal system.

Musculoskeletal fitness appears to be particularly important for elderly people and their ability to maintain functional independence. In fact, many activities of daily living do not require a large aerobic output but depend on one or more of the musculoskeletal fitness components. ${ }^{9,10}$ As previously stated, ${ }^{10}$ "Many healthy elderly people may be at or near the functional threshold for dependence, wherein they are in jeopardy of losing the capacity to carry out the activities of daily living. With further worsening of musculoskeletal fitness, an individual may lose the capacity to perform daily activities, such as getting out of a chair or climbing stairs." This represents a cycle of decline, where reduced musculoskeletal fitness leads to inactivity and further dependence. As illustrated in Fig. 3, improvements in musculoskeletal function have an enormous potential for delaying or eliminating the onset of disability, dependence and chronic disease. ${ }^{9,10}$ For instance, previous longitudinal investigations have revealed that people with high levels of muscular strength have fewer functional limitations ${ }^{102,103}$ and lower incidences of chronic diseases such as diabetes, stroke, arthritis, coronary artery disease and pulmonary disorders. ${ }^{103}$

Two recent systematic reviews ${ }^{9,10}$ have revealed that enhanced musculoskeletal fitness is positively associated with functional independence, mobility, glucose homeostasis, bone health, psychological well-being and overall quality of life and is negatively associated with the risk of falls, illness and premature death. Interventions that improve musculoskeletal fitness appear to be particularly important for improving the health status of frail elderly people (who have a low musculoskeletal reserve). ${ }^{9,10}$ This research has revealed clearly the importance of engaging in activities that tax the musculoskeletal system and is supported by findings from a recent epidemiologic investigation. ${ }^{104}$ This evidence provides direct support for the recent recommendation that resistance training and flexibility exercises be performed at least twice a week to maintain functional status, promote lifelong physical activity and enhance overall quality of life., ${ }^{3,105}$

\section{How much physical activity is enough?}

It is apparent that physical activity is essential in the prevention of chronic disease and premature death. ${ }^{14}$ However, doubt remains over the optimal "volume" (frequency, duration and intensity of exercise) and the minimum volume for health benefits, in particular the effects of intensity (e.g., moderate v. vigorous) on health status. There is evidence that intensity of physical activity is inversely and linearly associated with mortality. ${ }^{14}$ Early work by Paffenbarger and associates $^{106}$ revealed that regular physical activity (expending $>2000 \mathrm{kcal}[8400 \mathrm{k}]$ per week) was associated with an average increase in life expectancy of $\mathrm{I}$ to 2 years by the age of 80 and that the benefits were linear even at lower levels of energy expenditure. Subsequent studies have shown that an average energy expenditure of about rooo kcal (4200 kJ) per week is associated with a $20 \%-30 \%$ reduction in all-cause mortality. ${ }^{14,106,107}$ Currently, most health and fitness organizations and professionals advocate a minimum volume of exercise that expends $1000 \mathrm{kcal}$ (4200 kJ) per week and acknowledge the added benefits of higher energy expenditures.

Recently, investigators have postulated that even lower levels of weekly energy expenditure may be associated with health benefits. ${ }^{107-109} \mathrm{~A}$ volume of exercise that is about half of what is currently recommended may be sufficient, ${ }^{14}$ particularly for people who are extremely deconditioned or are frail and elderly. ${ }^{6}$ Future research is required to determine whether expending as little as $500 \mathrm{kcal}(2 \mathrm{I00} \mathrm{kJ})$ per week

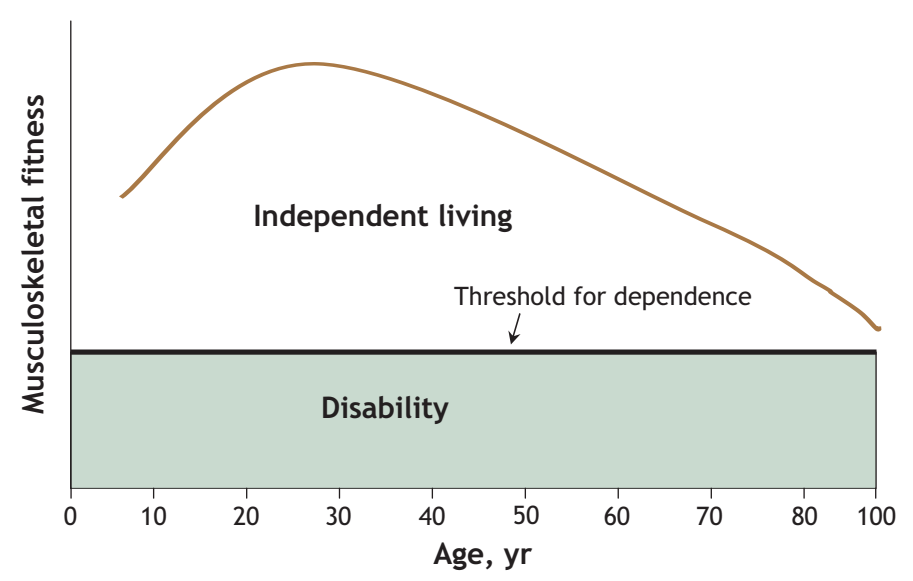

Fig. 3: Theoretical relation between musculoskeletal fitness and independent living across a person's lifespan. As a person ages, his or her musculoskeletal fitness (i.e., muscular strength, muscular endurance, muscular power or flexibility) declines, such that a small impairment may result in disability. Many elderly people currently live near or below the functional threshold for dependence. High levels of (or improvements in) musculoskeletal fitness will enhance the capacity to meet the demands of everyday life and allow a person to maintain functional independence for a greater period. ${ }^{., 10}$ 
offers health benefits. If so, then previously sedentary people may be more likely to engage in physical activity and maintain an active lifestyle.

The dose-response relation between physical activity and health status outlined above generally relates to cardiovascular disease and premature death from any cause. However, the same may hold true for other activity-associated health benefits. For instance, as mentioned earlier, moderately intense levels of exercise $(\geq 5.5$ METs for at least 40 minutes per week) and of cardiovascular fitness ( $>3 \mathrm{I} \mathrm{mL}$ oxygen per kilogram per minute) are effective preventive strategies against type 2 diabetes. ${ }^{48}$ In patients with type 2 diabetes, walking more than 2 hours per week has also been shown to reduce the risk of premature death. ${ }^{49}$

With respect to cancer, a review of the literature revealed that moderate physical activity ( $>4.5$ METs) for about 30-60 minutes per day had a greater protective effect against colon and breast cancer than activities of low intensity ${ }^{67}$ The greatest benefit for reducing the incidence of breast cancer was observed among women who engaged in 7 or more hours of moderate-to-vigorous activity per week. ${ }^{110}$ Among patients with established cancer, physical activity equivalent to walking I or more hours per week was associated with improved survival compared with no exercise. ${ }^{74}$ The greatest benefit was observed among cancer survivors who performed exercise equivalent to $3-5$ hours per week at an average pace. ${ }^{74}$

With respect to osteoporosis, the dose-response relation of physical activity is less clear. However, osteogenic adaptations appear to be load-dependent and site-specific. ${ }^{9,10,111}$ Accordingly, physical activities that require impact or significant loading are therefore advocated for optimal bone health. Running distances of up to $15-20$ miles $(24-32 \mathrm{~km})$ per week has been associated with the accrual or maintenance of bone mineral density, but longer distances may be associated with reduced bone mineral density. ${ }^{112}$

\section{How does physical activity and fitness lead to improved health outcomes?}

Several biological mechanisms may be responsible for the reduction in the risk of chronic disease and premature death associated with routine physical activity. For instance, routine physical activity has been shown to improve body composition (e.g., through reduced abdominal adiposity and improved weight control), ${ }^{9,10,113-116}$ enhance lipid lipoprotein profiles (e.g., through reduced triglyceride levels, increased highdensity lipoprotein [HDL] cholesterol levels and decreased low-density lipoprotein [LDL]-to-HDL ratios), ${ }^{9,10,117-123}$ improve glucose homeostasis and insulin sensitivity, ${ }^{3,9,10,124-126}$ reduce blood pressure, ${ }^{127-130}$ improve autonomic tone, ${ }^{131,132}$ reduce systemic inflammation; ${ }^{133}$ decrease blood coagulation, ${ }^{134,135}$ improve coronary blood flow, ${ }^{136}$ augment cardiac function ${ }^{137,138}$ and enhance endothelial function. ${ }^{139-142}$ Chronic inflammation, as indicated by elevated circulating levels of inflammatory mediators such as C-reactive protein, has been shown to be strongly associated with most of the chronic diseases whose prevention has benefited from exercise. Recent RCTs have shown that exercise training may cause marked reductions in C-reactive protein levels. ${ }^{143}$ Each of these factors may explain directly or indirectly the reduced incidence of chronic disease and premature death among people who engage in routine physical activity.

Routine physical activity is also associated with improved psychological well-being (e.g., through reduced stress, anxiety and depression ${ }^{9,10,144}$ ). Psychological well-being is particularly important for the prevention and management of cardiovascular disease, but it also has important implications for the prevention and management of other chronic diseases such as diabetes, osteoporosis, hypertension, obesity, cancer and depression.

Changes in endothelial function may be a particularly important adaptation to routine physical activity. Endothelial dysfunction has been observed with aging, smoking and multiple chronic disease states, including coronary artery disease, congestive heart failure, stroke, type 2 diabetes, hypertension, hypercholesterolemia and obesity. ${ }^{116}$ Regular aerobic activity has been found to improve vascular function in adults independent of changes in other risk factors ${ }^{142,145}$ and has been said to result in a shear-stress-mediated improvement in endothelial function, ${ }^{116}$ which confers a health benefit to a number of disease states. ${ }^{146}$

Although most research into the mechanisms of how physical activity and fitness improve health outcomes has dealt with the relation between cardiovascular disease and physical activity, researchers have also evaluated the primary mechanisms responsible for decreases in the risk and severity of individual disease states. In fact, despite the adaptations that are of global benefit for multiple disease states, physical activity also results in specific adaptations that affect individual disease states. For instance, in type 2 diabetes, adaptations that affect glucose homeostasis are of great importance. As reviewed by Ivy, ${ }^{147}$ a series of changes (independent of changes in body mass ${ }^{64}$ ) occur as a result of regular physical activity, including increased glycogen synthase $\mathrm{e}^{148}$ and hexokinase activity, ${ }^{149}$ increased GLUT-4 protein and mRNA expression, ${ }^{148,150}$ and improved muscle capillary density (resulting in improved glucose delivery to the muscle). ${ }^{149} \mathrm{~A}$ series of mechanisms may explain the $46 \%$ reduction in cancer rates observed with regular physical activity, ${ }^{66}$ including reductions in fat stores, ${ }^{66}$ increased energy expenditure offsetting a highfat diet, ${ }^{66}$ activity-related changes in sex hormone levels, immune function, insulin and insulin-like growth factors, freeradical generation, ${ }^{151}$ and direct effects on the tumour. ${ }^{151}$

The majority of proposed mechanisms have been discussed in the context of chronic adaptations brought about by routine physical activity. However, researchers have recently examined the importance of acute changes in risk factors for chronic disease. ${ }^{152}$ An excellent review of the topic by Thompson and colleagues revealed that acute, dynamic exercise may result in transient changes in the form of reductions in triglyceride levels, increases in HDL cholesterol level, decreases in blood pressure (for $12-16$ hours), reductions in insulin resistance and improvements in glucose control. ${ }^{152}$ These acute changes indicate the important role individual exercise sessions have on health status. 


\section{Summary}

There is incontrovertible evidence that regular physical activity contributes to the primary and secondary prevention of several chronic diseases and is associated with a reduced risk of premature death. There appears to be a graded linear relation between the volume of physical activity and health status, such that the most physically active people are at the lowest risk. However, the greatest improvements in health status are seen when people who are least fit become physically active. The current activity guidelines promoted by Health Canada appear to be sufficient to reduce health risk. People who engage in exercise at levels above those recommended in the guidelines are likely to gain further health benefits. Health promotion programs should target people of all ages, since the risk of chronic disease starts in childhood and increases with age.

In the next issue, we will review how to evaluate the healthrelated physical fitness and activity levels of patients and will provide exercise recommendations for health.

\section{This article has been peer reviewed.}

From the School of Human Kinetics, University of British Columbia (Warburton, Nicol, Bredin), and the Healthy Heart Program, St. Paul's Hospital (Warburton, Nicol), Vancouver, BC

Competing interests: None declared.

Contributors: Darren Warburton was responsible for the conception of the review and the writing of the manuscript. Shannon Bredin provided assistance with the writing of the manuscript and background research. Crystal Whitney Nicol provided assistance with background research. All of the authors critically reviewed the article for intellectual content and approved the final version.

Acknowledgements: This research was supported by the Michael Smith Foundation for Health Research, the Canadian Institutes of Health Research, the Canada Foundation for Innovation and the BC Knowledge Development Fund.

\section{REFERENCES}

I. Bouchard C, Shephard RJ. Physical activity fitness and health: the model and key concepts. In: Bouchard C, Shephard RJ, Stephens T, editors. Physical activity fitness and health: International proceedings and consensus statement. Champaign (IL): Human Kinetics; I994. p. 77-88.

2. Blair SN, Brodney S. Effects of physical inactivity and obesity on morbidity and mortality: current evidence and research issues. Med Sci Sports Exerc 1999;31:S646-62.

3. American College of Sports Medicine. Position stand: Exercise and physical activity for older adults. Med Sci Sports Exerc 1998;30:992-1008.

4. McAuley E. Physical activity and psychosocial outcomes. In: Bouchard C, Shephard RJ, Stephens T, editors. Physical activity, fitness and health: the consensus knowledge. Champaign (IL): Human Kinetics; I994. p. 55I-68.

5. Taylor RS, Brown A, Ebrahim S, et al. Exercise-based rehabilitation for patients with coronary heart disease: systematic review and meta-analysis of randomized controlled trials. Am J Med 2004; II6:682-92.

6. Blair SN, Cheng Y, Holder JS. Is physical activity or physical fitness more important in defining health benefits? [discussion S419-20]. Med Sci Sports Exerc 2001;33:S379-99.

7. Blair SN, Kohl HW, Paffenbarger RS Jr, et al. Physical fitness and all-cause mortality. A prospective study of healthy men and women. JAMA r989;262:2395-40I.

8. Paffenbarger RS Jr, Hyde RT, Hsieh CC, et al. Physical activity, other life-style patterns, cardiovascular disease and longevity. Acta Med Scand Suppl I986;7II:85-9I.

9. Warburton DE, Gledhill N, Quinney A. Musculoskeletal fitness and health. Can J Appl Physiol 2001;26:217-37.

Io. Warburton DE, Gledhill N, Quinney A. The effects of changes in musculoskeletal fitness on health. Can J Appl Physiol 200I;26:I6I-2I6.

II. U.S. Department of Health and Human Services. Healthy people 200o: national health promotion and disease prevention objectives. In. Washington: US Department of Health and Human Services; I99I.

I2. Puett DW, Griffin MR. Published trials of nonmedicinal and noninvasive therapies for hip and knee osteoarthritis. Ann Intern Med i994;121:133-40.

I3. Shephard RJ. Absolute versus relative intensity of physical activity in a doseresponse context. [discussion S4I9-20]. Med Sci Sports Exerc 200I;33:S400-I8.

I4. Lee IM, Skerrett PJ. Physical activity and all-cause mortality: What is the dose- response relation? [discussion S493-4]. Med Sci Sports Exerc 200I;33:S459-7I.

15. Canadian Community Health Survey. Ottawa: Statistics Canada; 2002/03.

I6. Morris JN, Heady JA, Raffle PA, et al. Coronary heart-disease and physical activity of work. Lancet I953;265:IIII-20.

I7. Morris JN, Heady JA. Mortality in relation to the physical activity of work: a preliminary note on experience in middle age. BrJ Ind Med 1953;10:245-54.

I8. Paffenbarger RS Jr, Brand RJ, Sholtz RI, et al. Energy expenditure, cigarette smoking, and blood pressure level as related to death from specific diseases. Am J Epidemiol 1978 ;108:12-8.

I9. Paffenbarger RS, Hale WE. Work activity and coronary heart mortality. $N$ Engl Med I975;292:545-50.

20. Kohl HW III. Physical activity and cardiovascular disease: evidence for a dose response. [discussion S493-4]. Med Sci Sports Exerc 200I;33:S472-83.

2I. Berlin JA, Colditz GA. A meta-analysis of physical activity in the prevention of coronary heart disease. Am J Epidemiol $1990 ; 132: 612-28$.

22. Powell KE, Thompson PD, Caspersen CJ, et al. Physical activity and the incidence of coronary heart disease. Annu Rev Public Health 1987;8:253-87.

23. Lee IM, Hsieh CC, Paffenbarger RS Jr. Exercise intensity and longevity in men. The Harvard Alumni Health Study. JAMA I995;273:1179-84.

24. Wannamethee SG, Shaper AG, Walker M. Changes in physical activity, mortality, and incidence of coronary heart disease in older men. Lancet 1998;351:1603-8.

25. Lee IM, Paffenbarger RS Jr. Associations of light, moderate, and vigorous intensity physical activity with longevity. The Harvard Alumni Health Study. Am J Epidemiol 2000;15I:293-9.

26. Oguma Y, Sesso HD, Paffenbarger RS Jr, et al. Physical activity and all cause mortality in women: a review of the evidence. BrJ Sports Med 2002;36:162-72.

27. Macera CA, Hootman JM, Sniezek JE. Major public health benefits of physical activity. Arthritis Rheum 2003;49:122-8.

28. Macera CA, Powell KE. Population attributable risk: implications of physical activity dose. [discussion 640-I]. Med Sci Sports Exerc 200I;33:S635-9.

29. Myers J, Kaykha A, George S, et al. Fitness versus physical activity patterns in predicting mortality in men. Am JMed 2004;117:912-8.

30. Hu FB, Willett WC, Li T, et al. Adiposity as compared with physical activity in predicting mortality among women. N Engl J Med 2004;351:2694-703.

31. Blair SN, Kampert JB, Kohl HW III, et al. Influences of cardiorespiratory fitness and other precursors on cardiovascular disease and all-cause mortality in men and women. JAMA I996;276:205-Io.

32. Wessel TR, Arant CB, Olson MB, et al. Relationship of physical fitness vs body mass index with coronary artery disease and cardiovascular events in women. IAMA 2004;292:1179-87.

33. Katzmarzyk PT, Church TS, Blair SN. Cardiorespiratory fitness attenuates the effects of the metabolic syndrome on all-cause and cardiovascular disease mortality in men. Arch Intern Med 2004;164:I092-7.

34. Erikssen G. Physical fitness and changes in mortality: the survival of the fittest. Sports Med 200I;31:57I-6.

35. Erikssen G, Liestol K, Bjornholt J, et al. Changes in physical fitness and changes in mortality. Lancet I998;352:759-62.

36. Blair SN, Kohl HW III, Barlow CE, et al. Changes in physical fitness and all-cause mortality. A prospective study of healthy and unhealthy men. JAMA I995;273:1093-8.

37. Bijnen FC, Feskens EJ, Caspersen CJ, et al. Baseline and previous physical activity in relation to mortality in elderly men: the Zutphen Elderly Study. Am J Epidemiol 1999;150:1289-96.

38. Myers J, Prakash M, Froelicher V, et al. Exercise capacity and mortality among men referred for exercise testing. N Engl J Med 2002;346:793-801.

39. Oguma Y, Shinoda-Tagawa T. Physical activity decreases cardiovascular disease risk in women: review and meta-analysis. Am J Prev Med 2004;26:407-18.

40. Wannamethee SG, Shaper AG, Walker M. Physical activity and mortality in older men with diagnosed coronary heart disease. Circulation 2000;102:1358-63.

4I. Jolliffe JA, Rees K, Taylor RS, et al. Exercise-based rehabilitation for coronary heart disease. Cochrane Database Syst Rev 200I;(I):CDooI8oo.

42. Hambrecht R, Niebauer J, Marburger C, et al. Various intensities of leisure time physical activity in patients with coronary artery disease: effects on cardiorespiratory fitness and progression of coronary atherosclerotic lesions. J Am Coll Cardiol 1993;22:468-77.

43. Franklin BA, Swain DP, Shephard RJ. New insights in the prescription of exercise for coronary patients. J Cardiovasc Nurs 2003;18:116-23.

44. Blumenthal JA, Rejeski WJ, Walsh-Riddle M, et al. Comparison of high- and lowintensity exercise training early after acute myocardial infarction. Am J Cardiol I988;6r:26-30.

45. Helmrich SP, Ragland DR, Paffenbarger RS Jr. Prevention of non-insulin-dependent diabetes mellitus with physical activity. Med Sci Sports Exerc 1994;26:824-30.

46. Helmrich SP, Ragland DR, Leung RW, et al. Physical activity and reduced occurrence of non-insulin-dependent diabetes mellitus. N Engl J Med I991;325:147-52.

47. Manson JE, Nathan DM, Krolewski AS, et al. A prospective study of exercise and incidence of diabetes among US male physicians. JAMA I992;268:63-7.

48. Lynch J, Helmrich SP, Lakka TA, et al. Moderately intense physical activities and high levels of cardiorespiratory fitness reduce the risk of non-insulin-dependent diabetes mellitus in middle-aged men. Arch Intern Med I996;156:1307-I4.

49. Gregg EW, Gerzoff RB, Caspersen CJ, et al. Relationship of walking to mortality among US adults with diabetes. Arch Intern Med 2003;163:I440-7.

50. Tuomilehto J, Lindstrom J, Eriksson JG, et al. Prevention of type 2 diabetes mellitus by changes in lifestyle among subjects with impaired glucose tolerance. $N$ Eng JMed 200I;344:1343-50.

5I. Laaksonen DE, Lindstrom J, Lakka TA, et al. Physical activity in the prevention of type 2 diabetes: the finnish diabetes prevention study. Diabetes 2005;54:158-65. 
52. Williamson DF, Vinicor F, Bowman BA. Primary prevention of type 2 diabetes mellitus by lifestyle intervention: implications for health policy. Ann Intern Med 2004;I40:95I-7.

53. Knowler WC, Barrett-Connor E, Fowler SE, et al. Reduction in the incidence of type diabetes with lifestyle intervention or metformin. NEngl JMed 2002;346:393-403.

54. Wei M, Gibbons LW, Kampert JB, et al. Low cardiorespiratory fitness and physical inactivity as predictors of mortality in men with type 2 diabetes. Ann Intern Med 2000;132:605-II.

55. Katzmarzyk PT, Church TS, Janssen I, et al. Metabolic syndrome, obesity, and mortality: impact of cardiorespiratory fitness. Diabetes Care 2005;28:39I-7.

56. Agurs-Collins TD, Kumanyika SK, Ten Have TR, et al. A randomized controlled trial of weight reduction and exercise for diabetes management in older AfricanAmerican subjects. Diabetes Care 1997;20:1503-II.

57. Dunstan DW, Daly RM, Owen N, et al. High-intensity resistance training improves glycemic control in older patients with type 2 diabetes. Diabetes Care 2002;25:1729-36

58. Dunstan DW, Daly RM, Owen N, et al. Home-based resistance training is not sufficient to maintain improved glycemic control following supervised training in older individuals with type 2 diabetes. Diabetes Care 2005;28:3-9.

59. Dunstan DW, Mori TA, Puddey IB, et al. The independent and combined effects of aerobic exercise and dietary fish intake on serum lipids and glycemic control in NIDDM. A randomized controlled study. Diabetes Care 1997;20:913-21.

6o. Cauza E, Hanusch-Enserer U, Strasser B, et al. The relative benefits of endurance and strength training on the metabolic factors and muscle function of people with type 2 diabetes mellitus. Arch Phys Med Rehabil 2005;86:1527-33.

6r. Holten MK, Zacho M, Gaster M, et al. Strength training increases insulin-mediated glucose uptake, GLUT4 content, and insulin signaling in skeletal muscle in patients with type 2 diabetes. Diabetes 2004;53:294-305

62. Honkola A, Forsen T, Eriksson J. Resistance training improves the metabolic profile in individuals with type 2 diabetes. Acta Diabetol I997;34:245-8.

63. Hsia J, Wu L, Allen C, et al. Physical activity and diabetes risk in postmenopausal women. Am J Prev Med 2005;28:19-25

64. Boule NG, Haddad E, Kenny GP, et al. Effects of exercise on glycemic control and body mass in type 2 diabetes mellitus: a meta-analysis of controlled clinical trials. JAMA 2001;286:1218-27.

65. Lee IM. Physical activity and cancer prevention — data from epidemiologic studies. Med Sci Sports Exerc 2003;35:I823-7.

66. Shephard RJ, Futcher R. Physical activity and cancer: How may protection be maximized? Crit Rev Oncog 1997;8:219-72.

67 . Thune I, Furberg AS. Physical activity and cancer risk: dose-response and cancer, all sites and site-specific. [discussion S609-I0]. Med Sci Sports Exerc 200I;33:S530-50.

68. Paffenbarger RS Jr, Lee IM, Wing AL. The influence of physical activity on the incidence of site-specific cancers in college alumni. Adv Exp Med Biol I992;322:7-I5.

69. Wannamethee G, Shaper AG, Macfarlane PW. Heart rate, physical activity, and mortality from cancer and other noncardiovascular diseases. Am J Epidemiol I993; I37:735-48

70. Kampert JB, Blair SN, Barlow CE, et al. Physical activity, physical fitness, and allcause and cancer mortality: a prospective study of men and women. Ann Epidemiol $1996 ; 6: 452-7$.

71. Sesso HD, Paffenbarger RS Jr, Lee IM. Physical activity and breast cancer risk in the College Alumni Health Study (United States). Cancer Causes Control I998;9:433-9.

72. Rohan TE, Fu W, Hiller JE. Physical activity and survival from breast cancer. Eur J Cancer Prev I995;4:419-24.

73. Courneya KS, Jones LW, Fairey AS, et al. Physical activity in cancer survivors: implications for recurrence and mortality. Cancer Therapy 2004;2:I-I2.

74. Holmes MD, Chen WY, Feskanich D, et al. Physical activity and survival after breast cancer diagnosis. JAMA 2005;293:2479-86.

75. Haydon AM, Macinnis R, English D, et al The effect of physical activity and body size on survival after diagnosis with colorectal cancer. Gut 2005;1:62-7

76. Cunningham AJ, Edmonds CV, Jenkins GP, et al. A randomized controlled trial of the effects of group psychological therapy on survival in women with metastatic breast cancer. Psychooncology $1998 ; 7: 508-17$.

77. Jones LW, Eves ND, Courneya KS, et al. Effects of exercise training on antitumor efficacy of doxorubicin in MDA-MB-23I breast cancer xenografts. Clin Cancer Res 2005;II:6695-8.

78. Adamsen L, Midtgaard J, Rorth M, et al. Feasibility, physical capacity, and health benefits of a multidimensional exercise program for cancer patients undergoing chemotherapy. Support Care Cancer 2003;II:707-16.

79. McKenzie DC. Abreast in a boat - a race against breast cancer. CMAJ I998;159(4): 376-8.

8o. McKenzie DC, Kalda AL. Effect of upper extremity exercise on secondary lymphedema in breast cancer patients: a pilot study. JClin Oncol 2003;21:463-6.

8I. Segal RJ, Reid RD, Courneya KS, et al. Resistance exercise in men receiving androgen deprivation therapy for prostate cancer. J Clin Oncol 2003;2I:I653-9.

82. Galvao DA, Newton RU. Review of exercise intervention studies in cancer patients. JClin Oncol 2005;23:899-909.

83. Berard A, Bravo G, Gauthier P. Meta-analysis of the effectiveness of physical activity for the prevention of bone loss in postmenopausal women. Osteoporos Int 1997;7:331-7.

84. Kelley GA. Exercise and regional bone mineral density in postmenopausal women a meta-analytic review of randomized trials. Am J Phys Med Rehabil I998;77:76-87.

85. Kelley G. Aerobic exercise and lumbar spine bone mineral density in postmenopausal women: a meta-analysis. J Am Geriatr Soc 1998;46:143-52.

86. Bonaiuti D, Shea B, Iovine R, et al. Exercise for preventing and treating osteoporosis in postmenopausal women. Cochrane Database Syst Rev 2002;(3):CDoo0333

87. Wolff I, van Croonenborg J, Kemper HC, et al. The effect of exercise training pro- grams on bone mass: a meta-analysis of published controlled trials in pre- and postmenopausal women. Osteoporos Int I999;9:I-I2.

88. Tinetti ME, Baker DI, McAvay G, et al. A multifactorial intervention to reduce the risk of falling among elderly people living in the community. NEnglJMed I994;331:82I-7.

89. Wolf SL, Barnhart HX, Kutner NG, et al. Reducing frailty and falls in older persons: an investigation of Tai Chi and computerized balance training. Atlanta FICSIT Group. Frailty and Injuries: Cooperative Studies of Intervention Techniques. JAm Geriatr Soc 1996;44:489-97.

9o. Carter ND, Khan KM, Petit MA, et al. Results of a ro week community based strength and balance training programme to reduce fall risk factors: a randomised controlled trial in 65-75 year old women with osteoporosis. BrJ Sports Med 200I;35:348-5I.

91. Liu-Ambrose T, Khan KM, Eng JJ, et al. Resistance and agility training reduce fall risk in women aged 75 to 85 with low bone mass: a 6-month randomized, controlled trial. J Am Geriatr Soc 2004;52:657-65.

92. Shaw JM, Snow CM. Weighted vest exercise improves indices of fall risk in older women. J Gerontol A Biol Sci Med Sci 1998;53:M53-8.

93. Gregg EW, Pereira MA, Caspersen CJ. Physical activity, falls, and fractures among older adults: a review of the epidemiologic evidence. J Am Geriatr Soc 2000;48:883-93.

94. Stevens JA, Powell KE, Smith SM, et al. Physical activity, functional limitations, and the risk of fall-related fractures in community-dwelling elderly. Ann Epidemiol I997;7:54-6I.

95. Carter ND, Kannus P, Khan KM. Exercise in the prevention of falls in older people: a systematic literature review examining the rationale and the evidence. Sports Med 200I;31:427-38.

96. Kujala UM, Kaprio J, Kannus P, et al. Physical activity and osteoporotic hip fracture risk in men. Arch Intern Med 2000;160:705-8.

97. Joakimsen RM, Fonnebo V, Magnus JH, et al. The Tromso Study: physical activity and the incidence of fractures in a middle-aged population. $J$ Bone Miner Res I998;13:1149-57.

98. Liu-Ambrose TY, Khan KM, Eng JJ, et al. Both resistance and agility training increase cortical bone density in 75- to 85 -year-old women with low bone mass: a 6 month randomized controlled trial. J Clin Densitom 2004;7:390-8.

99. Kemmler W, Lauber D, Weineck J, et al. Benefits of 2 years of intense exercise on bone density, physical fitness, and blood lipids in early postmenopausal osteopenic women: results of the Erlangen Fitness Osteoporosis Prevention Study (EFOPS). Arch Intern Med 2004;164:1084-91.

Ioo. Williams PT. Physical fitness and activity as separate heart disease risk factors: a meta-analysis. Med Sci Sports Exerc 200I;33:754-6r.

IoI. Sirard JR, Pate RR. Physical activity assessment in children and adolescents. Sports Med 200I;3I:439-54

I02. Brill PA, Macera CA, Davis DR, et al. Muscular strength and physical function. Med Sci Sports Exerc 2000;32:412-6.

I03. Rantanen T, Masaki K, Foley D, et al. Grip strength changes over $27 \mathrm{yr}$ in JapaneseAmerican men. J Appl Physiol 1998;85:2047-53.

I04. Katzmarzyk PT, Craig CL. Musculoskeletal fitness and risk of mortality. Med Sc Sports Exerc 2002;34:740-4.

105. Blair SN, LaMonte MJ, Nichaman MZ. The evolution of physical activity recommendations: How much is enough? Am J Clin Nutr 2004;79:913S-20S.

Io6. Paffenbarger RS Jr, Hyde RT, Wing AL, et al. Physical activity, all-cause mortality, and longevity of college alumni. N Engl J Med I986;314:605-I3.

I07. Paffenbarger RS Jr, Hyde RT, Wing AL, et al. The association of changes in physical-activity level and other lifestyle characteristics with mortality among men. $N$ Engl J Med I993;328:538-45.

108. Kushi LH, Fee RM, Folsom AR, et al. Physical activity and mortality in postmenopausal women. JAMA I997;277:1287-92.

Io9. Leon AS, Connett J, Jacobs DR Jr., et al. Leisure-time physical activity levels and risk of coronary heart disease and death. The Multiple Risk Factor Intervention Trial. JAMA i987;258:2388-95.

IIo. Rockhill B, Willett WC, Hunter DJ, et al. A prospective study of recreational physical activity and breast cancer risk. Arch Intern Med i999;159:2290-6.

III. Kerr D, Morton A, Dick I, et al. Exercise effects on bone mass in postmenopausal women are site-specific and load-dependent. J Bone Miner Res I996;11:218-25.

II2. Brown JP, Josse RG. 2002 clinical practice guidelines for the diagnosis and management of osteoporosis in Canada [published errata in $C M A J$ 2003;I68(4):400, 2003;168(6):676 and 2003;168(5):544]. CMAJ 2002;167(Io Suppl):SI-34.

II3. Seidell JC, Cigolini M, Deslypere JP, et al. Body fat distribution in relation to physical activity and smoking habits in 38-year-old European men. The European Fat Distribution Study. Am J Epidemiol I991;133:257-65.

II4. Tremblay A, Despres JP, Leblanc C, et al. Effect of intensity of physical activity on body fatness and fat distribution. Am J Clin Nutr 1990;51:153-7.

II5. Slattery ML, McDonald A, Bild DE, et al. Associations of body fat and its distribution with dietary intake, physical activity, alcohol, and smoking in blacks and whites. Am J Clin Nutr 1992;55:943-9.

II6. Maiorana A, O'Driscoll G, Taylor R, et al. Exercise and the nitric oxide vasodilator system. Sports Med 2003;33:1013-35.

II7. Berg A, Halle M, Franz I, et al. Physical activity and lipoprotein metabolism: epidemiological evidence and clinical trials. EurJMed Res 1997;2:259-64.

II8. Halle M, Berg A, von Stein T, et al. Lipoprotein(a) in endurance athletes, power athletes, and sedentary controls. Med Sci Sports Exerc I996;28:062-6.

II9. O'Connor GT, Hennekens CH, Willett WC, et al. Physical exercise and reduced risk of nonfatal myocardial infarction. Am J Epidemiol I995;142:1147-56.

I20. DuRant RH, Baranowski T, Rhodes T, et al. Association among serum lipid and lipoprotein concentrations and physical activity, physical fitness, and body composition in young children. J Pediatr 1993;123:185-92. 
I2I. Tell GS, Vellar OD. Physical fitness, physical activity, and cardiovascular disease risk factors in adolescents: the Oslo Youth Study. Prev Med I988;17:I2-24.

I22. Taimela S, Viikari JS, Porkka KV, et al. Lipoprotein (a) levels in children and young adults: the influence of physical activity. The Cardiovascular Risk in Young Finns Study. Acta Paediatr 1994;83:1258-63.

123. Brenes G, Dearwater S, Shapera R, et al. High density lipoprotein cholesterol concentrations in physically active and sedentary spinal cord injured patients. Arch Phys Med Rehabil I986;67:445-50.

I24. Wallberg-Henriksson H, Rincon J, Zierath JR. Exercise in the management of noninsulin-dependent diabetes mellitus. Sports Med I998;25:25-35

I25. Young JC. Exercise prescription for individuals with metabolic disorders. Practical considerations. Sports Med I995; I9:43-54

I26. Kelley DE, Goodpaster BH. Effects of physical activity on insulin action and glucose tolerance in obesity. Med Sci Sports Exerc r999;31:S6I9-23.

I27. Blair SN, Goodyear NN, Gibbons LW, et al. Physical fitness and incidence of hypertension in healthy normotensive men and women. JAMA I984;252:487-90.

I28. American College of Sports Medicine. Position stand: Physical activity, physical fitness, and hypertension. Med Sci Sports Exerc 1993;25:i-x.

I29. Paffenbarger RS Jr, Jung DL, Leung RW, et al. Physical activity and hypertension: an epidemiological view. Ann Med ig9I;23:319-27.

I30. Paffenbarger RS Jr, Wing AL, Hyde RT, et al. Physical activity and incidence of hypertension in college alumni. Am J Epidemiol I983;117:245-57.

I3I. Adamopoulos S, Piepoli M, McCance A, et al. Comparison of different methods for assessing sympathovagal balance in chronic congestive heart failure secondary to coronary artery disease. Am J Cardiol I992;70:1576-82.

I32. Tiukinhoy S, Beohar N, Hsie M. Improvement in heart rate recovery after cardiac rehabilitation. J Cardiopulm Rehabil 2003;23:84-7.

I33. Adamopoulos S, Parissis J, Kroupis C, et al. Physical training reduces peripheral markers of inflammation in patients with chronic heart failure. Eur Heart J 200I;22:79I-7.

I34. Physical activity and cardiovascular health. NIH Consensus Development Panel on Physical Activity and Cardiovascular Health. JAMA 1996;276:24I-6.

I35. Rauramaa R, Salonen JT, Seppanen K, et al. Inhibition of platelet aggregability by moderate-intensity physical exercise: a randomized clinical trial in overweight men. Circulation I986;74:939-44

I36. Hambrecht R, Wolf A, Gielen S, et al. Effect of exercise on coronary endothelia function in patients with coronary artery disease. N Engl J Med 2000;342:454-6o.

I37. Warburton DER, Gledhill N, Jamnik V, et al. Induced hypervolemia, cardiac function, $\mathrm{VO}_{2 \max }$ and performance of elite cyclists. Med Sci Sports Exerc I999;31:80o-8.

138. Warburton DE, Haykowsky MJ, Quinney HA, et al. Blood volume expansion and cardiorespiratory function: effects of training modality. Med Sci Sports Exerc 2004;36:99I-I000.

I39. Gokce N, Vita JA, Bader DS, et al. Effect of exercise on upper and lower extremity endothelial function in patients with coronary artery disease. Am J Cardiol 2002;90:124-7.

I40. Kobayashi N, Tsuruya Y, Iwasawa T, et al. Exercise training in patients with chronic heart failure improves endothelial function predominantly in the trained extremities. Circ J 2003;67:505-I0.

I4I. Hambrecht R, Gielen S, Linke A, et al. Effects of exercise training on left ventricular function and peripheral resistance in patients with chronic heart failure: a randomized trial. JAMA 2000;283:3095-I0I.

I42. McGavock J, Mandic S, Lewanczuk R, et al. Cardiovascular adaptations to exercise training in postmenopausal women with type 2 diabetes mellitus. Cardiovasc Diabetol 2004;3:3.

I43. Nicklas BJ, You T, Pahor M. Behavioural treatments for chronic systemic inflammation: effects of dietary weight loss and exercise training [review]. CMAJ 2005; I72(9):II99-209.

I44. Dunn AL, Trivedi MH, O'Neal HA. Physical activity dose-response effects on outcomes of depression and anxiety. [discussion 6o9-Io]. Med Sci Sports Exerc 200I;33:S587-97.

I45. Ferreira I, Twisk JW, Stehouwer CD, et al. Longitudinal changes in $\mathrm{VO}_{2 \max }$ : associations with carotid IMT and arterial stiffness. Med Sci Sports Exerc 2003;35:1670-8.

146. Laughlin MH, Joseph B. Wolfe Memorial lecture. Physical activity in prevention and treatment of coronary disease: the battle line is in exercise vascular cell biology. Med Sci Sports Exerc 2004;36:352-62.

I47. Ivy JL. Role of exercise training in the prevention and treatment of insulin resistance and non-insulin-dependent diabetes mellitus. Sports Med I997;24:32I-36.

I48. Christ-Roberts CY, Pratipanawatr T, Pratipanawatr W, et al. Exercise training increases glycogen synthase activity and GLUT4 expression but not insulin signaling in overweight nondiabetic and type 2 diabetic subjects. Metabolism 2004;53:1233-42.

I49. Mandroukas K, Krotkiewski M, Hedberg M, et al. Physical training in obese women. Effects of muscle morphology, biochemistry and function. Eur J Appl Physiol Occup Physiol I984;52:355-6I.

I50. Dela F, Ploug T, Handberg A, et al. Physical training increases muscle GLUT4 protein and mRNA in patients with NIDDM. Diabetes I994;43:862-5.

I5I. Westerlind KC. Physical activity and cancer prevention - mechanisms. Med Sci Sports Exerc 2003;35:1834-40.

I52. Thompson PD, Crouse SF, Goodpaster B, et al. The acute versus the chronic response to exercise. [discussion S452-3]. Med Sci Sports Exerc 2001;33:S438-45.

Correspondence to: Dr. Darren E.R. Warburton, Cardiovascular Physiology and Rehabilitation Laboratory, University of British Columbia, Unit II, Osborne Centre, 6ro8 Thunderbird Blvd., Vancouver BC V6TIZ3; fax 604 822-945I; darren.warburton@ubc.ca
Appendix 1: A glossary of commonly used terms

Active daily living: The implementation of physical activity as an integral and meaningful part of daily living

Activities of daily living: The activities one engages in during daily life

Aerobic training: An exercise program that incorporates activities that are rhythmic in nature, using large muscle groups at moderate intensities for 3 to 5 days per week

Cardiovascular fitness: The ability to transport and use oxygen during prolonged, strenuous exercise or work. It reflects the combined efficiency of the lungs, heart, vascular system and exercising muscles in the transport and use of oxygen

Exercise: Structured and repetitive physical activity designed to maintain or improve physical fitness

Health-related physical fitness: The components of physical fitness that are related to health status, including cardiovascular fitness, musculoskeletal fitness, body composition and metabolism

Heart rate reserve: The difference between the maximum heart rate (predicted or determined directly) and the resting heart rate $\left(H R_{\max }-H R_{\text {rest }}\right)$

$\%$ heart rate reserve: This formula takes into account the resting and maximum heart rates to provide an appropriate target heart rate (or range) for training:

Training heart rate $=\left(\left[\mathrm{HR}_{\max }-\mathrm{HR}_{\text {rest }}\right] \times 40 \%-85 \%\right)+\mathrm{HR}_{\text {rest }}$

Maximum aerobic power: The maximum amount of oxygen that can be transported and used by the working muscles; also known as maximal oxygen consumption $\left(\mathrm{VO}_{2 \max }\right)$

Metabolic equivalent (MET): An estimate of one's resting metabolic rate while sitting quietly $(1 \mathrm{MET}=3.5 \mathrm{~mL}$ oxygen per kilogram per minute, or $1 \mathrm{kcal}$ [4.2 kJ] per kilogram per hour)

Musculoskeletal fitness: The fitness of the musculoskeletal system, encompassing muscular strength, muscular endurance, muscular power, flexibility, back fitness and bone health

Physical activity: All leisure and non-leisure body movements resulting in an increased energy output from the resting condition

Physical fitness: A physiologic state of well-being that allows one to meet the demands of daily living or that provides the basis for sport performance, or both

Quality of life: An overall satisfaction and happiness with life. It includes the facets of physiologic, emotional, functional and spiritual well-being

Resistance training: An exercise program that uses repeated, progressive contractions of specific muscle groups to increase muscle strength, endurance or power

$\mathrm{VO}_{2}$ reserve: The difference between the maximum and resting oxygen consumption $\left(\mathrm{VO}_{2 \max }-\mathrm{VO}_{2 \text { rest }}\right)$

$\% \mathrm{VO}_{2}$ reserve: This formula takes into account the resting and maximum oxygen consumption to provide an appropriate level (or range) for training:

Training $\mathrm{VO}_{2}=\left(\left[\mathrm{VO}_{2 \max }-\mathrm{VO}_{2 \text { rest }}\right] \times 40 \%-85 \%\right)+\mathrm{VO}_{2 \text { rest }}$ 